Available online at http://journal.stkip-andi-matappa.ac.id/index.php/histogram/index

Histogram : Jurnal Pendidikan Matematika 4(1),2020, 177 - 189

\title{
PENGARUH PENERAPAN PENDEKATAN \\ PEMBELAJARAN KONTEKSTUAL TERHADAP HASIL BELAJAR MATEMATIKA
}

\author{
Ira Irviana ${ }^{1^{*}}$, Muhammad Ilyas Ismail ${ }^{2}$ \\ ${ }^{1}$ Universitas Islam Makassar, ${ }^{2}$ UIN Alauddin \\ * Corresponding Author. Email: irairviana90@yahoo.com \\ Received: 02 Januari 2020; Revised: 22 Januari 2020 ; Accepted: 30 Maret 2020
}

\begin{abstract}
ABSTRAK
Penelitian ini bertujuan untuk (1) mengetahui gambaran hasil belajar matematika murid SD Inpres BTN IKIP 1 Makassar; (2) mengetahui gambaran penerapan pendekatan kontekstual dalam pembelajaran matematika di kelas IV SD Inpres BTN IKIP 1 Makassar; (3) mengetahui pengaruh penerapan pendekatan kontekstual terhadap hasil belajar matematika murid di SD Inpres BTN IKIP 1 Makassar. Penelitian ini adalah jenis penelitian quasi eksperimen. Populasi dalam penelitian ini adalah seluruh siswa di SD Inpres BTN IKIP 1 Makassar tahun 2017, sampel penelitian yaitu murid kelas IV SD Inpres BTN IKIP I Makassar. Teknik pengumpulan data melalui tes hasil belajar matematika dan lembar observasi. Teknik analisis data statistik deskriptif dan inferensial. Hasil penelitian menunjukkan : (1) Hasil belajar siswa dalam pembelajaran matematika di kelas IV SD Inpres BTN IKIP 1 Makassar sebelum penerapan pendekatan kontekstual berada pada kategori sangat rendah, setelah penerapan pendekatan kontekstual berada pada kategori sangat tinggi. Sedangkan pada kelompok kontrol berada pada kategori sangat rendah ke kategori rendah; (2) penerapan pendekatan kontekstual pada umumnya terlaksana dengan baik berdasarkan hasil dan pelaksanaannya. (3) penerapan pendekatan kontekstual berpengaruh terhadap hasil belajar pada mata pelajaran matematika siswa kelas IV SD Inpres BTN IKIP 1 Makassar.
\end{abstract}

Kata Kunci: Kontekstual, Hasil Belajar, Matematika

\section{ABSTRACT}

This study aims to (1) find out the picture of mathematics learning results of students of SD Inpres BTN IKIP 1 Makassar; (2) to know the description of the application of contextual approach in mathematics learning in grade IV of SD Inpres BTN IKIP 1 Makassar; (3) determine the effect of applying contextual approach to the results of mathematics learning of students at SD Inpres BTN IKIP 1 Makassar. This research is a type of quasi research experiment. The population in this study was all students at SD Inpres BTN IKIP 1 Makassar in 2017, a sample of research that is grade 4 students of SD Inpres BTN IKIP I Makassar. Data collection techniques through mathematics study results tests and observation sheets. Descriptive and inferential statistical data analysis techniques. The results showed: (1) Students' learning outcomes in mathematics learning in grade IV of SD Inpres BTN IKIP 1 Makassar before the application of contextual approaches are in a very low category after the application of contextual approaches are in a very high category. While in the control group is in a very low category to a low category; (2) The application of contextual approach is generally carried out properly based on the results and implementation. (3) The application of contextual approach affects the learning outcomes in mathematics subjects of grade 4 students of SD Inpres BTN IKIP 1 Makassar.

Keywords: Contextual, Learning Outcomes, Mathematics

How to Cite: Irviana, I. , \& Ismail, M, I. (2020). Pengaruh Penerapan Pendekatan Pembelajaran Kontekstual terhadap Hasil Belajar Matematika. Histogram: Jurnal $\begin{array}{llllll}\text { Pendidikan } \quad \text { Matematika, } & 4(1), & 177 & - & 189, & \text { doi: }\end{array}$ http://dx.doi.org/10.31100/histogram.v4i1.532

Copyright $\subset$ 2020, THE AUTHOR (S). This article distributed under the CC-BY-SA-license. 


\section{Histogram: Jurnal Pendidikan Matematika, 4 (1), 2020 - 178 Ira Irviana ${ }^{1}$, Muhammad Ilyas Ismail ${ }^{2}$}

Permalink/DOI: http://dx.doi.org/10.31100/histogram.v4i1.532

\section{PENDAHULUAN}

\section{A. Latar Belakang}

Pendidikan merupakan segala usaha yang dilakukan secara sadar dan terencana dan bertujuan mengubah tingkah laku manusia kearah yang lebih baik dan sesuai dengan yang diharapkan. Pendidikan akan merangsang kreativitas seseorang agar sanggup menghadapi tantangan-tantangan alam, masyarakat, teknologi serta kehidupan yang makin kompleks. Indonesia di penghujung abad XX, dilihat dari jumlah penduduknya telah menjadi negara terbesar ke lima di dunia. Jumlah yang besar ini sebenarnya merupakan potensi pembangunan apabila diimbangi dengan kualitas sumber daya manusia yang baik. Pembangunan nasional membutuhkan SDM yang berkualitas yang memiliki sikap dan tekad kemandirian. Kualitas SDM dapat ditingkatkan melalui pendidikan.

Dalam Proses pembelajaran matematika, seorang guru memiliki peran penting dalam menyampaikan informasi, melatih keterampilan dan membimbing belajar murid sehingga para guru dituntut memiliki kualifikasi dan kompetensi tertentu, agar proses belajar dan pembelajaran dapat berlangsung efektif dan efisien. Adanya minat yang tinggi, serta metode pembelajaran yang tepat akan menjadikan murid mudah dalam menerima dan mengolah informasi yang disampaikan. Kemampuan mengelola proses belajar mengajar merupakan kecakapan para guru dalam menciptakan suasana komunikasi yang edukatif antara guru dan peserta didik yang mencakup segi kognitif, afektif, dan psikomotor, sebagai upaya mempelajari sesuatu berdasarkan perencanaan sampai dengan tahap evaluasi dan tindak lanjut hingga tercapai tujuan pengajaran.”

Uraian tersebut dapat diasumsikan bahwa mata pelajaran matematika mempunyai peran yang strategis dan penting dalam mempersiapkan sumber daya manusia yang unggul, handal, dan bermoral semenjak dini. Hal yang menjadi hambatan selama ini dalam pembelajaran matematika adalah disebabkan kurang dikemasnya pembelajaran matematika dengan metode yang menarik, menantang, dan menyenangkan. Para guru seringkali menyampaikan materi matematika dengan cara konvensional, sehingga pembelajaran matematika cenderung membosankan bagi murid, yang pada gilirannya prestasi belajar murid kurang memuaskan.

Berdasarkan hasil observasi dilapangan bahwa masih ada siswa yang kesulitan dalam pembelajaran matematika hal ini terlihat dari ketidak tuntasan dalam pembelajaran matematika berdasar pernyataan guru dilapangan bahwa dari 52 murid kelas IV hanya ada 


\section{Histogram: Jurnal Pendidikan Matematika, 4 (1), 2020 - 179 Ira Irviana ${ }^{1}$, Muhammad Ilyas Ismail ${ }^{2}$}

12 murid yang mengalami ketuntasan belajar matematika yang menjadi acuan dalam hal ini adalah KKM untuk mata pelajaran matematika adalah 75 dan 40 murid berada dibawah nilai KKM . Hal lain yang menyebabkan sulitnya matematika karena kurang begitu bemakna. Bila murid belajar matematika terpisah dari pengalaman sehari-hari maka murid akan cepat lupa dan tidak dapat mengaplikasikan matematika.

Belajar matematika bisa menyenangkan asal tidak hanya dilakukan dibelakang meja saja, dimana murid biasanya harus menghadapi setumpuk buku dan berbagai macam pekerjaan rumah. Matematika biasa dipelajari dengan suasana menyenangkan bagi murid. Sistem pendidikan sekarang banyak mengalami perubahan dimana kreatifitas anak diharapkan untuk dapat tumbuh dan berkembang sehingga menjadi manusia yang dapat meningkatkan kualitas hidupnya serta inisiatif dan kreatifitasnya akan berkembang.

Matematika merupakan salah satu bidang studi yang menduduki peranan penting dalam pendidikan, hal ini dapat dilihat dari waktu jam pelajaran sekolah lebih banyak dibanding pelajaran lain, Berdasarkan pengamatan peneliti dalam proses pembelajaran, ada tiga indikator yang menunjukkan hal ini. Pertama, murid kurang memiliki keberanian untuk menyampaikan pendapat kepada orang lain. Kedua, kurang adanya keinginan untuk mencapai hasil belajar yang optimal. Ketiga, kurangnya semangat belajar murid dalam mempelajari matematika di SD Inpres BTN IKIP 1 Makassar Hal ini terlihat dari hasil obeservasi yang dilakukan dilapangan. Maka pada setiap pembelajaran matematika berlangsung murid kurang merespon materi yang disampaikan oleh guru, pasif, bersikap masa bodoh, cerita dengan teman sebangku, tidak mempunyai catatan, tidak mau membawa buku paket atau buku penunjang, dan guru terlihat mendominasi aktivitas serta kegiatan pembelajaran bermuara pada ceramah. Akhirnya, hasil belajar yang dicapai sangat tidak memuaskan. Peneliti memilih pelajaran matematika sebab ditinjau dari nilai para murid yang kurang memuaskan yakni rata rata berada dibawah kkm yaitu 80 untuk mata pelajaran matematika di SD Inpres BTN IKIP 1 Makassar.

Idealnya pembelajaran matematika seharusnya pembelajaran yang menyenangkan dan menantang bagi siswa. Berdasarkan hakekat pendidikan sebagaimana dinyatakan dalam pasal 1 UndangUndang Nomor 20 Tahun 2003 yang menyatakan sebagai berikut: "Pendidikan adalah usaha sadar dan terencana untuk mewujudkan suasana belajar dan proses pembelajaran agar murid secara aktif mengembangkan potensi dirinya untuk memiliki kekuatan spiritual keagamaan, pengendalian diri, kepribadian, kecerdasan, akhlak mulia, serta keterampilan yang diperlukan dirinya, masyarakatnya bangsa dan negaranya. Dengan demikian para guru diharapkan senantiasa dapat meningkatkan peranannya dalam 


\section{Histogram: Jurnal Pendidikan Matematika, 4 (1), 2020 - 180 Ira Irviana ${ }^{1}$, Muhammad Ilyas Ismail ${ }^{2}$}

menempatkan pembelajaran yang berkualitas untuk mengantarkan para murid meraih prestasi belajar yang maksimal. Dengan prestasi yang maksimal itu diharapkan para murid dapat mengikuti perkembangan ilmu pengetahuan dan teknologi yang semakin cepat.

Melalui pengenalan metode baru dalam pembelajaran oleh Departemen Pendidikan Nasional, seperti metode pembelajaran kontekstual atau contextual teaching learning diharapkan dapat meningkatkan kualitas pembelajaran di kelas yang muara akhirnya dapat meningkatkan hasil belajar matematika murid. Contextual Teaching and Learning (CTL) adalah suatu strategi pembelajaran yang menekankan kepada proses keterlibatan murid secara penuh untuk menemukan materi yang dipelajari dan menghubungkannnya dengan situasi kehidupan nyata sehingga mendorong murid untuk dapat menerapkannya dalam kehidupan mereka. Dari pengertian tersebut terlihat bahwa metode ini lebih banyak memberikan kepada peserta didik untuk lebih aktif bukan hanya mendengar, lebih dari itu peserta didik diharapkan mencari berbagai informasi mengenai pelajarannya sehingga guru yang dikenal hanya sebagai pengajar sekarang menjadi partner murid.

Melalui penerapan metode kontekstual yang dianggap bisa membantu siswa agar lebih memahami pembelajaran matematika dan reposisi peran guru dan murid dalam pembelajaran, maka kegiatan pembelajaran itu akan menjadi efektif sehingga dapat mencapai tujuan pembelajaran yang diharapkan yaitu meningkatkan kualitas pembelajaran dan prestasi murid. Menurut Ahmad Munif (2003 : 4), sekolah dikatakan efektif bilamana proses pembelajaran dapat mencapai tujuan yang ditetapkan dengan baik yang berimplikasi pada upaya guru dalam mengembangkan system pembelajaran secara profesional berdasarkan kurikulum yang ditetapkan.

Berdasarkan pemaparan diatas maka peneliti dalam hal ini ingin melihat bagaimana hasil belajar murid dalam penerapan metode pembelajaran kontekstual yang digunakan oleh para guru, terutama dalam pembelajaran matematika di SD Inpres BTN IKIP 1 Makassar sehingga, rumusan masalah dalam penelitian ini adalah sebagai berikut : (1) Bagaimanakah gambaran hasil belajar matematika murid SD Inpres BTN IKIP 1 Makassar ?; (2) Bagaimanakah gambaran penerapan pendekatan kontekstual dalam pembelajaran matematika di kelas IV SD Inpres BTN IKIP 1 Makassar ?; (3) Apakah ada pengaruh penerapan pendekatan kontekstual terhadap hasil belajar matematika murid di SD Inpres BTN IKIP 1 Makassar? 


\section{Histogram: Jurnal Pendidikan Matematika, 4 (1), 2020 - 181 Ira Irviana ${ }^{1}$, Muhammad Ilyas Ismail ${ }^{2}$}

\section{METODE PENELITIAN}

\section{A. Jenis dan Desain Penelitian}

Penelitian ini adalah jenis penelitian true experiment (experiment penuh). Desain penelitian eksperimen yang digunakan adalah pretest-posttest control group design

\section{B. Variabel Penelitian}

Variabel bebas dalam penelitian ini adalah penerapan pembelajaran kontekstual pada mata pelajaran matematika. Variabel terikat dalam penelitian ini adalah penguasaan matematika murid melalui hasil belajar yang dicapai sebelum dan setelah murid diberi perlakuan. Hasil belajar yang dimaksud adalah tingkat pencapaian belajar yang diukur dengan tes.

\section{Populasi dan Sampel}

Seluruh satuan pembelajaran matematika yang terjadi di semester yang berjalan selama penelitian ini berlangsung di Kelas IV SD Inpres BTN IKIP 1 Makassar. Dengan jumlah murid di kelas IV sebanyak 52 murid yang terdiri dari 28 murid laki-laki dan 24 murid perempuan. Dalam penelitian ini ditetapkan dua kelas kegiatan pembelajaran matematika yaitu yang menggunakan pembelajaran kontekstual dan menggunakan pembelajaran konvensional biasa pada murid kelas IV di SD Inpres BTN IKIP I Makassar pada semester genap tahun 2017. Kelas eksperimen terdiri dari 26 murid sedangkan kelas kontrol terdiri dari 26 murid.

\section{B. Teknik Pengumpulan Data}

Instrumen pengukuran yang digunakan dalam penelitian meliputi:

\section{Tes hasil belajar matematika}

Tes hasil belajar digunakan untuk mengukur tingkat penguasaan peserta didik dalam mata pelajaran matematika. Instrumen digunakan untuk melihat hasil belajar kognitif murid yang dilakukan dalam bentuk tes pilihan ganda. Untuk tes dilakukan uji validitas dan realibilitas secara data empirik. Semua soal adalah materi dari pembelajaran matematika.

\section{Lembar Observasi}

Lembar Observasi digunakan untuk mengukur dan menilai proses belajar yaitu gambaran pelaksanaan pengunaan pembelajaran kontekstual dan tingkah laku murid pada saat pembelajaran. Observasi dalam penelitian ini hasil pngamatannya diberi nilai atau disediakan nilai dengan angka 5, 4, 3, 2, 1 yang bermakna sebagai skala nilai 


\section{Histogram: Jurnal Pendidikan Matematika, 4 (1), 2020 - 182 Ira Irviana ${ }^{1}$, Muhammad Ilyas Ismail ${ }^{2}$}

\section{Teknik Analisis Data}

\section{Analisis Data Deskriptif}

Berdasarkan Kriteria Ketuntasan Minimum (KKM) belajar Matematika kelas IV yaitu 80, sumber data berasal dari guru kelas SD Inpres BTN IKIP I Makassar. Kriteria ketuntasan menunjukkan persentase tingkat pencapaian kompetensi sehingga dinyatakan dengan angka maksimum 100 (seratus). Angka maksimum 100 merupakan kriteria ketuntasan ideal. Target ketuntasan secara nasional diharapkan mencapai minimal 80. Jika kriteria yang digunakan berdasarkan KKM Mata Pelajaran matematika kelas IV, maka kategori ini adalah Tinggi. apabila didasarkan teknik kategorisasi standar yang ditetapkan oleh Departemen Pendidikan dan Kebudayaan.

\section{Analisis Data Inferensial}

\section{a. Uji normalitas}

Hasil uji normalitas menunjukkan bahwa pada taraf sig. 95\% atau alpha $(\alpha) 0,05$ tersebut diperoleh nilai sig. (2-tailed) 0,077 untuk kelas kontrol dan pada kelas eksperimen diperoleh nilai sig. (2-tailed) 0,103. Sehingga dapat disimpulkan bahwa data pada kelas eksperimen maupun kontrol berdistribusi normal.

\section{b. Uji homogenitas}

Hasil uji homogenitas menunjukkan nilai posttest pada kelompok eksperimen dan kontrol yaitu 0,737 lebih besar dari 0,05 sehingga dapat dinyatakan bahwa data penelitian berasal dari populasi yang mempunyai varian sama.

\section{c. Uji Hipotesis}

Untuk mendapatkan gambaran hasil perhitungan pengujian hipotesis melalui formula Uji Dua Pihak hasil belajar matematika sebelum dan sesudah perlakuan, diperoleh hasil perhitungan hasil belajar, pada taraf signifikan $5 \%$.

\section{HASIL PENELITIAN DAN PEMBAHASAN}

\section{A. Hasil Penelitian}

\section{Gambaran hasil belajar Matematika murid SD Inpres BTN IKIP 1 Makassar}

Berdasarkan pengamatan peneliti dalam proses pembelajaran, ada tiga indikator yang menunjukkan hal ini. Pertama, murid kurang memiliki keberanian untuk menyampaikan pendapat kepada orang lain. Kedua, kurang adanya keinginan untuk mencapai hasil belajar yang optimal. Ketiga, kurangnya semangat belajar murid dalam mempelajari matematika di SD Inpres BTN IKIP 1 Makassar Hal ini terlihat dari hasil obeservasi yang dilakukan dilapangan. Setelah peneliti dalam hal ini menerapkan ISSN: 2549-6700 (print), ISSN 2549-6719 (online) 


\section{Histogram: Jurnal Pendidikan Matematika, 4 (1), 2020 - 183 Ira Irviana ${ }^{1}$, Muhammad Ilyas Ismail ${ }^{2}$}

pembelajaran kontekstual maka ditemukan hasil belajar matematika diukur menggunakan instrumen berupa tes hasil belajar (soal) yang berjumlah dua puluh item pertanyaan. Sebelum tes hasil belajar diberikan pada kelas eksperimen dan kontrol terlebih dahulu divalidasi oleh ahli materi dan pembelajaran. Dalam hal ini yang menjadi validator ahli hasil belajar. Selanjutnya diberikan kepada 20 responden diluar sampel penelitian dan diperolelah lima belas item tes hasil belajar yang valid.

Setelah instrumen tes hasil belajar diujikan diperoleh data pretest dan data posttest sebagai berikut.

Tabel 1. Gambaran hasil belajar siswa sebelum dan sesudah perlakuan

\begin{tabular}{|c|c|c|c|c|c|c|c|c|c|}
\hline \multicolumn{4}{|c|}{ Kelompok eksperimen } & \multirow{3}{*}{ Interval } & \multirow{3}{*}{ Kategori } & \multicolumn{4}{|c|}{ Kelompok control } \\
\hline \multicolumn{2}{|c|}{ Pretest } & \multicolumn{2}{|c|}{ Posttest } & & & \multicolumn{2}{|c|}{ Pretest } & \multicolumn{2}{|c|}{ Posttest } \\
\hline$F$ & $\%$ & $F$ & $\%$ & & & $f$ & $\%$ & $f$ & $\%$ \\
\hline 0 & 0 & 14 & 53,85 & $86-100$ & Sangat tinggi & 0 & 0 & 2 & 7,69 \\
\hline 1 & 3,85 & 7 & 26,92 & $71-85$ & Tinggi & 2 & 7,69 & 4 & 15,38 \\
\hline 5 & 19,23 & 5 & 19,23 & $56-70$ & Sedang & 6 & 23,08 & 8 & 30,77 \\
\hline 8 & 30,77 & 0 & 0 & $41-55$ & Rendah & 7 & 26,92 & 10 & 38,46 \\
\hline 12 & 46,15 & 0 & 0 & $<40$ & Sangat rendah & 11 & 42,31 & 2 & 7,69 \\
\hline 26 & 100 & 26 & 100 & & nlah & 26 & 100 & 26 & 100 \\
\hline
\end{tabular}

(Sumber : Data Primer, Tahun: 2017)

\section{a. Gambaran Hasil Belajar Siswa Sebelum Diberi Perlakuan pendekatan kontekstual}

Tabel 1 menunjukkan bahwa pada kelompok eksperimen sebelum diberikan perlakuan pendekatan kontekstual, hasil belajar di SD Inpres BTN IKIP 1 Makassar sebanyak 1 orang siswa pada kategori tinggi dengan persentase $3,85 \%$, pada sedang sebanyak 5 orang anak dengan persentase 19,23\%, pada kategori rendah sebanyak 8 orang anak dengan persentase $30,77 \%$ dan pada kategori sangat rendah sebanyak 12 orang anak dengan persentase $46,15 \%$. Sedangkan pada kelompok kontrol sebelum pembelajaran (pretest) hasil belajar di SD Inpres BTN IKIP 1 Makassar sebanyak 2 orang siswa pada kategori tinggi dengan persentase 7,69\%, pada kategori sedang sebanyak 6 orang anak dengan persentase $23,08 \%$, pada kategori rendah sebanyak 7 orang anak dengan persentase $26,92 \%$ dan pada kategori sangat rendah sebanyak 11 orang anak dengan persentase $42,31 \%$. 


\section{Histogram: Jurnal Pendidikan Matematika, 4 (1), 2020 - 184 Ira Irviana ${ }^{1}$, Muhammad Ilyas Ismail ${ }^{2}$}

\section{b. Gambaran hasil siswa sesudah diberi perlakuan}

Kuesioner hasil belajar untuk posttest sama dengan pretest. Hal itu agar tidak terjadi bias antara pretest dan posttest. Kuesioner hasil belajar untuk posttest berjumlah 15 item pernyataan yang memiliki rentang nilai $0-100$. Skor hasil siswa yang diajarkan dengan menggunakan pendekatan kontekstual (kelompok eksperimen) diperoleh skor tertinggi adalah 100 dan terendah adalah 60. Siswa yang diajarkan dengan metode ceramah (kelas kontrol) memiliki skor tertinggi adalah 80 dan terendah adalah 33 .

Setelah diberikan perlakuan pendekatan kontekstual, hasil belajar siswa mengalami peningkatan. Pada kategori sangat tinggi terdapat 14 orang siswa dengan nilai persentase $53,85 \%$, pada kategori tinggi terdapat 7 orang siswa dengan nilai persentase $26,92 \%$, pada kategori sedang terdapat 5 orang siswa dengan nilai persentase $19,23 \%$. Sedangkan pada kelompok kontrol Pada kategori sangat tinggi terdapat 2 orang siswa dengan nilai persentase $7,69 \%$, pada kategori tinggi terdapat 4 orang siswa dengan nilai persentase $15,38 \%$, pada kategori sedang terdapat 8 orang siswa dengan nilai persentase $30,77 \%$, pada kategori rendah terdapat 10 orang siswa dengan nilai persentase $38,46 \%$ dan sangat rendah terdapat 2 orang siswa dengan nilai persentase $7,69 \%$.

Hal tersebut menunjukkan bahwa hasil belajar siswa kelas eksperimen mengalami peningkatan yang besar jika dibandingkan dengan saat pretest. Rendahnya hasil belajar siswa pada kelas kontrol ini disebabkan kurang tepatnya pemilihan metode pembelajaran yang digunakan untuk hasil siswa.

Hasil posttest siswa kelas eksperimen mengalami peningkatan yang lebih baik, yaitu dari kualifikasi rendah menjadi tinggi. Tingginya nilai posttest siswa terjadi akibat model pembelajaran yang digunakan pendekatan kontekstual dapat meningkatkan kemapuan bekerjasama siswa dalam pembelajaran matematika. Hal itu dikarenakan terjadi pembelajaran yang menyenangkan dan melibatkan semua siswa dalam kegiatan pembelajaran.

\section{Gambaran penerapan pendekatan kontekstual dalam pembelajaran Matematika di kelas IV SD Inpres BTN IKIP 1 Makassar}

Penerapan langkah-langkah penerapan pendekatan kontekstual dalam pembelajaran Matematika di kelas IV SD Inpres BTN IKIP 1 Makassar sebagai berikut:

(1) Konstruktivisme; (2) Inquiri (menemukan); (3) Questioning (bertanya); (4) Learning community (masyarakat belajar); (5)Modeling (pemodelan); (6) Reflection (refleksi); (6) 


\section{Histogram: Jurnal Pendidikan Matematika, 4 (1), 2020 - 185 Ira Irviana ${ }^{1}$, Muhammad Ilyas Ismail ${ }^{2}$}

Authentic assessment (penilaian sebenarnya), Secara keseluruhan pelaksanaan penerapan pendekatan kontekstual dalam pembelajaran Matematika terlaksana dengan baik.

\section{Pengaruh penerapan pendekatan kontekstual terhadap hasil belajar Matematika murid di SD Inpres BTN IKIP 1 Makassar}

Berdasarkan hasil perhitungan uji perbedaan dua rata-rata (uji-t) dapat diketahui bahwa nilai hasil pengujian hipotesis yang disajikan bahwa secara keseluruhan bahwa thitung $=6,456$. Rangkuman hasil perhitungan uji-t dapat dilihat pada Tabel 2. sebagai berikut :

Tabel 2. Rangkuman hasil perhitungan uji-t

\begin{tabular}{ccccc}
\hline No & $\begin{array}{c}\text { Kelompok yang } \\
\text { dibandingkan }\end{array}$ & $\mathbf{t}_{\text {hitung }}$ & $\mathbf{t}_{\text {tabel 0,05 }}$ & Keterangan \\
\hline 1 & $\begin{array}{c}\text { Posttest } \text { Eksperimen dan } \\
\text { kontrol }\end{array}$ & 6,456 & 2,00856 & Signifikan \\
\hline
\end{tabular}

(Sumber : Data Primer, Tahun: 2017)

Berdasarkan Tabel 2 menunjukkan bahwa perhitungan uji-t menunjukkan hasil perhitungan tentang perbedaan keefektifan antara kedua metode pembelajaran secara keseluruhan bahwa $t_{\text {hitung }}=6,456>\mathrm{t}_{\text {tabel }}=2,00856$ pada taraf Signifikan $\alpha=0.05$, dengan demikian $\mathrm{H}_{0}$ ditolak dan hipotesis alternatif $\mathrm{H}_{1}$ diterima. Maka hasil belajar antara kelompok siswa yang diberikan pendekatan kontekstual lebih tinggi dibandingkan dengan kelompok siswa yang tidak diberikan pendekatan kontekstual (Ceramah).

Hasil Perhitungan uji-t dapat disimpulkan bahwa terdapat perbedaan pengaruh yang signifikan antara kelompok siswa yang diberikan pendekatan kontekstual dan kelompok siswa yang tidak diberikan pendekatan kontekstual (ceramah) terhadap hasil belajar siswa. Oleh karena itu, hasil belajar siswa yang diberikan pendekatan kontekstual lebih baik secara nyata dibandingkan yang diberikan ceramah. Hal ini berarti hipotesis penelitian secara keseluruhan adalah hasil belajar siswa yang diberikan pendekatan kontekstual lebih tinggi dibandingkan dengan kelompok siswa yang diberikan ceramah.

\section{B. Pembahasan}

Jika dibandingkan data hasil belajar siswa yang diberikan penerapan pendekatan kontekstual pada mata matematika murid SD Inpres BTN IKIP 1 Makassar dengan hasil belajar siswa yang tidak diberikan penerapan pendekatan kontekstual menunjukan keunggulan pada kelas eksperimen yang tidak ada lagi siswa memiliki hasil belajar rendah dan sangat rendah sedangkan pada kelas kotrol masih ada siswa yang berada pada kategori tersebut. Hal ini membuktikan bahwa pendekatan pembelajaran yang baik, pada dasarnya 


\section{Histogram: Jurnal Pendidikan Matematika, 4 (1), 2020 - 186 Ira Irviana ${ }^{1}$, Muhammad Ilyas Ismail ${ }^{2}$}

tergantung kebutuhan guru. Sebaiknya sesuai dengan materi yang akan diberikan pada waktu itu, pendekatan yang baik, sebaiknya mampu membuat siswa aktif dalam proses pembelajaran bukan sebaliknya. Pemilihan pendekatan sebaiknya mengacu kepada kebutuhan peserta didik guna mempermudah proses belajar siswa. Menurut (Elaine B. Johnson, 2007) pendekatan pembelajaran merupakan kegiatan yang dipilih yang dapat memberikan fasilitas atau bantuan kepada peserta didik untuk mencapai tujuan pembelajaran.

Ada tujuh komponen utama pendekatan kontekstual yang terdiri atas: “(a) komponen konstruktivisme, (b) komponen inkuiri, (c) komponen bertanya, (d) komponen masyarakat belajar, (e) komponen pemodelan, (f) komponen refleksi, dan (g) komponen penilaian", (Nurhadi, 2003).

Pelaksanaan pembelajaran dengan menggunakan pendekatan kontekstual dalam penelitian ini dipilih karena dipandang dapat mengoptimalkan interaksi semua unsur pembelajaran. Hal ini terlihat dari upaya yang dilakukan guru untuk meningkatkan pemahaman terhadap materi operasi hitung bilangan adalah terlebih dahulu mengecek pemahaman siswa tentang materi tersebut. Tetapi kenyataannya hampir seluruh siswa belum memahami materi tersebut, oleh karena itu peneliti lebih dulu memberikan pemahaman tentang materi operasi hitung bilangan. Dengan mengecek materi prasyarat dapat menjadikan dasar atau landasan guru dalam memberikan tindakan dalam penelitian ini. Hal ini sejalan dengan salah satu ciri pembelajaran dengan pendekatan kontekstual yaitu "pengetahuan prasyarat merupakan pengalaman awal peserta didik dan situasi pengetahuan yang didapat mereka akan berarti atau bernilai dan nampak sebagai dasar dalam pembelajaran”, (Aisyah. Nyimas, Hawa, S., Purwoko, \& Masrinawatie, 2007).

Setelah mengetahui pengetahuan prasyarat, peneliti melakukan pembelajaran dengan pendekatan kontekstual, siswa dihadapkan langsung pada pengalaman nyata mereka dengan menyebutkan contoh bilangan yang pernah ditemukan dalam kehidupan sehari-hari siswa. Siswa diberikan permasalahan dan dibiasakan untuk memecahkan masalah dengan selalu memberikan pertanyaan-pertanyaan yang mengacu pada materi sehingga menemukan konsep materi dari diri siswa. Guru tidak langsung memberikan penjelasan tentang materi operasi hitung bilangan, tetapi memberikan kesempatan kepada siswa untuk mengkonstruksikan pengetahuan awal tentang materi tersebut yang ada dibenak mereka sehingga dapat menemukan pengetahuan baru dan mentransformasikannya pada kehidupan nyata siswa dibimbing untuk menemukan konsep materi operasi hitung bilangan dengan mengembangkan ide-ide, bekerja dengan kelompok 


\section{Histogram: Jurnal Pendidikan Matematika, 4 (1), 2020 - 187 Ira Irviana ${ }^{1}$, Muhammad Ilyas Ismail ${ }^{2}$}

dengan menggunakan. Hal ini sejalan dengan paham konstruktivisme (Nurhadi, 2003) bahwa "manusia membangun atau menciptakan pengetahuan dengan cara memberi arti pada pengetahuan sesuai pengalamannya".

Diawal pertemuan mulanya masih banyak siswa yang pasif, belum berani mengeluarkan gagasan-gagasan dan ide-ide dalam benak mereka terutama dalam menjawab pertanyaan yang diberikan oleh guru. Hal ini disebabkan karena pembelajaran dengan menggunakan pendekatan CTL memang merupakan hal yang baru dialami oleh siswa dalam pembelajaran matematika. Selain itu juga mereka malu untuk bertanya kepada guru tentang apa yang belum mereka mengerti. Akan tetapi setelah dibimbing dan terbiasa pada pertemuan selanjutnya, mereka sudah mengetahui materi operasi hitung bilangan dengan baik dan benar. Siswa-siswa sudah sering bertanya tentang ha-hal yang belum dipahami tanpa malu-malu. Hal ini sesuai dengan pendapat Sadker dan Cooper (Nurhadi, 2003) yang menegaskan "pentingnya bertanya dalam proses pembelajaran di kelas guna merangsang siswa dalam berpikir, mengevaluasi belajar, memulai pengajaran, mempertegas gagasan dan meyakinkan apa yang diketahui siswa".

Kegiatan inti pada penelitian ini, siswa bekerja dalam kelompok melakukan pengamatan terhadap materi operasi hitung bilangan. Pembagian kelompok didasarkan pada tingkat pemahaman siswa. Pada pertemuan pertama, hasil kerja kelompok kurang maksimal hal ini dikarenakan para siswa tidak terbiasa berkelompok dalam kegiatan pembelajaran matematika namun setelah beberapa pertemuan selanjutnya hasil kerja siswa mulai meningkat. Hal ini sesuai dengan salah satu komponen pendekatan kontekstual yang melaksanakan pembelajaran dalam kelompok-kelompok belajar (masyarakat belajar) yang anggotanya heterogen dengan tujuan siswa yang pandai mengajari yang lemah dan yang tahu memberi tahu yang tidak tahu.

Kegiatan inti, siswa juga diarahkan untuk mengamati contoh-contoh materi operasi hitung bilangan yang sudah disediakan oleh guru. Aktivitas ini dilakukan siswa dalam kelompok sambil menyelesaikan permasalahan dan pertanyaan yang terdapat dalam LKS. Kegiatan ini selain dapat menciptakan pengalaman yang menyenangkan siswa, juga dapat melibatkan siswa secara fisik dan mental dalam belajar sehingga siswa dapat membangun pengetahuannya. Pengalaman bersentuhan langsung dengan objek belajarnya menjadi sangat penting terutama untuk siswa SD yang berada pada tahap operasi konkret yang mempelajari materi matematika secara langsung berdasarkan kehidupan sehari-hari. Hal ini sesuai dengan yang diungkapkan Piaget (Pitajeng, 2006) bahwa "perkembangan belajar anak melalui empat tahap yaitu tahap konkret, semi konkret, semi abstrak dan abstrak". 


\section{Histogram: Jurnal Pendidikan Matematika, 4 (1), 2020 - 188 Ira Irviana ${ }^{1}$, Muhammad Ilyas Ismail ${ }^{2}$}

Langkah terakhir untuk mengoptimalkan pemahaman siswa tentang materi operasi hitung bilangan, guru melakukan refleksi dan siswa diberi kesempatan untuk menyelesaikan soal-soal tentang materi operasi hitung bilangan baik selama proses pembelajaran maupun tugas yang mereka kerjakan di rumah agar siswa banyak berlatih. Hasil evaluasi dalam setiap proses pembelajaran menunjukkan bahwa pada dasarnya kebanyakan siswa merasa senang dan terlihat aktif dalam proses pembelajaran.

Berdasarkan uraian diatas jelaslah sudah bahwa dengan menggunakan pendekatan Contextual Teaching and Learning (CTL) dapat meningkatkan pemahaman siswa dalam pembelajaran matematika khususnya pada materi operasi hitung bilangan. Dimana materi yang abstrak dalam penelitian ini dapat disajikan secara konkret karena siswa membangun pengetahuan dalam benaknya sendiri melalui pengalaman nyata. Hal ini sesuai dengan yang diungkapkan oleh landasan filosofi konstruktivisme bahwa "melalui pendekatan kontekstual siswa diharapkan belajar melalui mengalami bukan menghafal" (Nurhadi, 2003). Oleh karena itu pendekatan CTL memungkinkan untuk dijadikan sebagai salah satu model pembelajaran dalam meningkatkan prestasi siswa dalam pembelajaran matematika khususnya di SD.

\section{KESIMPULAN DAN SARAN}

\section{A. Kesimpulan}

Berdasarkan rumusan masalah, tujuan penelitian, dan hasil yang diperoleh sebagaimana yang telah diuraikan pada bab sebelumnya, maka pada bagian ini disajikan kesimpulan sebagai implikasi dari hasil yang diperoleh. Adapun kesimpulan sebagai berikut: (1) Hasil belajar siswa dalam pembelajaran matematika di kelas IV SD Inpres BTN IKIP 1 Makassar sebelum penerapan pendekatan kontekstual berada pada kategori sangat rendah, setelah penerapan pendekatan kontekstual berada pada kategori sangat tinggi. Sedangkan pada kelompok kontrol berada pada kategori sangat rendah ke kategori rendah; (2) Penerapan pendekatan kontekstual yang terdiri dari tahap konstruktivisme, inquiri (menemukan), questioning (bertanya), learning community (masyarakat belajar), modeling (pemodelan), reflection (refleksi), authentic assessment (penilaian sebenarnya) pada umumnya terlaksana dengan baik berdasarkan hasil dan pelaksanaannya. (3) Penerapan pendekatan kontekstual berpengaruh terhadap hasil belajar pada mata pelajaran Matematika siswa kelas IV SDN IKIP Inpres BTN IKIP 1 Makassar. 


\section{Histogram: Jurnal Pendidikan Matematika, 4 (1), 2020 - 189 Ira Irviana ${ }^{1}$, Muhammad Ilyas Ismail ${ }^{2}$}

\section{B. Saran}

Sesuai dengan kesimpulan tersebut, maka dapat diajukan beberapa saran sebagai berikut: (1) Bagi guru diharapkan agar menerapkan pendekatan kontekstual sebagai alternatif model pembelajaran untuk meningkatkan hasil belajar siswa; (2) Kepala sekolah hendaknya berperan sebagai inisiator agar guru menggunakan Penerapan pendekatan kontekstual pada pembelajaran matematika; (3) Bagi peneliti selanjutnya, khususnya yang berkecimpung dalam pendidikan dasar, disarankan bagi peneliti yang berhasil untuk melakukan kajian lebih lanjut dan lebih mendalam.

\section{DAFTAR PUSTAKA}

Aisyah. Nyimas, Hawa, S., S., Purwoko, \& Masrinawatie. (2007). Pengembangan Pembelajaran Matematika SD. Jakarta: Direktorat Jenderal Pendidikan Tinggi Departemen Nasional.

Elaine B. Johnson. (2007). Contextual Teaching and Learning. Bandung: MLC.

Nurhadi. (2003). Pembelajaran Kontekstual dan Penerapannya dalam KBK. Malang: Universitas Negeri Malang.

Pitajeng. (2006). Pembelajaran matematika yang Menyenangkan. Jakarta: Depdiknas Direktorat Jenderal Pendidikan Tinggi Direktorat Ketenagaan. 